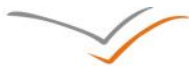

\title{
VERSITA
}

\section{Croatia's participation in the Seventh Framework Programme: a Moderate Success?}

\author{
Hrvoje Mataković, Iva Radočaj Novak \\ University of Zagreb, Centre for Research, Development and Technology Transfer, Croatia
}

\begin{abstract}
Background: The Framework Programme (FP7) is the main instrument of the EU for financing research, and participation in the programme benefits greatly to countries' technological development. Objectives: The aim of this paper is to assess the participation of Croatian organisations in FP7 in terms of specific programmes, funding schemes and the coordinator organisations. Methods: In order to assess this participation, two analyses have been done: the first is the analysis of participation itself analysing the basic characteristics of Croatian participation in FP7 using participation data. The second analysis is the analysis of external conditions for participation, i.e. a framework that influenced the quantity and the quality of participation in FP7. Results: Participation of Croatian institutions in the FP7 has the following features: the positive rate of the national and the EU financial contribution; an unequal regional distribution; a small number of projects coordinated by Croatian participants; a low success rate and rare participation in large research projects. Conclusions: Support should be provided to researchers in order to increase the participation in future funding programmes. First, researchers should perform only research and not the project administration since it requires well-educated and trained administration staff. Second, participants in future projects, especially coordinators, should be financially rewarded.
\end{abstract}

Keywords: Seventh Framework Programme, European Union, Croatia, research policy

JEL main category: Economic Development, Technological Change, and Growth

JEL classification: $\mathrm{O} 32$

Paper type: Research article

Received: 13 August 2013

Revised: 26 September

Accepted: 15 October 2013

Citation: Mataković, H., Radočaj Novak, I. (2013), "Croatia's participation in the Seventh Framework Programme: a Moderate Success?", Business Systems Research, Vol. 4, No. 2 , pp.126-143.

DOI: 10.2478/bsrj-2013-0017

\section{Introduction}

European Union (EU) Framework Programmes support the European R\&D system in order to create and strengthen the European Research Area (ERA). Most of the projects financed within Framework Programmes include organisations from different countries (mainly EU and Europe, but also from other parts of the world), thus resulting in a "tangle of cooperative networks" (Gusmão, 2001). Through participation in projects with partners of different profiles, participating institutions increase their scientific and technological capabilities and also strengthen contacts with prominent partners (Ortega et al., 2010). 
The first Framework Programme began in 1984 with average yearly budget of less than 1 billion Euro. Amendments to the European legislation during the 1980s and 1990s, such as the Single European Act in 1986 and the Maastricht Treaty in 1992, contribute to the growing impact of the Framework Programmes (Gusmão, 2001). Over time, Framework Programmes become the main instrument of the EU for funding of scientific research.

The Republic of Croatia began its participation in Framework Programmes during the Fifth Framework Programme (FP5), which lasted from 1998 to 2002. The results were modest since in FP5 Croatia had the status of a so-called "third country". Croatia participated in 29 projects with 37 participants, and the total amount of EU financial contribution to Croatian participants was 282.400 Euro (MZOŠ, 2008). According to the FP5 rules, "third countries" had no obligation to pay the national contribution for participation, but also their financing was possible only through the Specific International Scientific Cooperation Activities (INCO) subprogramme. In 2005, Croatia applied for full membership in the Framework Programmes, and participation in the Seventh Framework Programme (FP7) was listed as one of the objectives of the Science and Technology Policy of Republic of Croatia 2006-2010, adopted by the Government in April 2006 (MZOŠ, 2008).

Croatia became a member of the Framework Programmes on January 1, 2006 and thus able to fully participate in all calls, which was previously not possible. The status change and full membership in the Framework Programmes significantly influenced the Croatian results in Sixth Framework Programme (FP6) through increase in both the number of participants and the EU financial contribution. In the period between 2003 and 2006, 64 grants were signed with 72 participants, and with 6 million Euro of EU financial contribution. During 2006, the last year of the FP6 and the first year of Croatia's full membership in the Framework Programmes, 70 grants with 82 participants were signed, with a total value of 10, 2 million Euro of EU financial contribution (MZOŠ, 2008), and it was a significant increase after the first three years of participation in the status of "third country". Since national contribution was 6, 4 million Euro, it can be concluded that in the FP6 EU financial contribution to Croatia was 9,8 million Euro higher than national contribution.

The aim of this paper is to assess the participation of Croatian organisations in the Seventh Framework Programme, since "the sum of national participations in EU projects in itself amounts to a 'research system' of undeniable strategic importance" (Gusmão, 2001, 391). In order to assess this participation, in this paper two analyses will be done: the first being analysis of participation itself, where the basic characteristics of Croatian participation in FP7 will be analysed through participation data. The second analysis will be the analysis of external conditions for participation, therefore, framework that influenced quantity and quality of participation in FP7. The results will be explained by analysing external conditions and participation characteristics and their mutual correlation.

The contribution of this paper is to conduct a thorough analysis of the Croatian participation in FP7. According to the authors' knowledge, similar research has not been done before; in papers published by Rivera León and Reid (León Rivera and Reid, 2010) and Švarc et al. (Švarc et al., 2013) Croatia was discussed briefly, as just one of countries that were included in analysis. This work is also much more detailed than the paper in which first three years of FP7 (2007-2009) was analysed (Mataković, 2011).

\section{Methodology}

In this paper, data on the first six and a half years of the Seventh Framework Programme will be used. The Seventh framework programme has duration of 7 years, from the beginning of 2007 to the end of 2013. This data will allow an analysis of almost the entire FP7, since at the time of writing (July 2013), all of the largest calls have been closed, and the results of those few that are currently open cannot significantly affect the overall results. Data used in this study were taken from the Community Research and Development Information Service (CORDIS) database. CORDIS database is a public database containing information on EU funded research projects and project participants since 1990. CORDIS projects database generally includes basic information about each project: objectives, costs, start and end date, contract type and participants. On project participants, database includes information on the participating organisation, contact person, contact details and URL. The data was 
downloaded on July 13th 2013 - the analysis will include all data from the beginning of 2007 until July 13th 2013. These data will be supplemented with data on the finances from eCORDA database. eCORDA database gives limited access and the financial data from the database, due to the confidentiality rule, can be published only in the aggregate amounts or percentages.

Several papers (Barber et al., 2006; Roediger-Schluga et al., 2007; Ernst et al., 2010) described the shortcomings of the CORDIS database:, shortcomings are mainly related to incomplete data, long periods between signing of grant agreement and publishing projects in the database and lack of publishing of the project activities results. In these papers data from FP5 and FP6 were used, and complaints mentioned there are fully justified. In the meantime the database was refined and supplemented, and the data for FP7 is much more comprehensive compared to data from previous Framework Programmes. However, some problems are still present.

Firstly, there is no possibility of data download in a user friendly format (e.g. Excel sheet). Therefore, for the purposes of this paper, a programme was designed that accessed the web page of each FP7 project that, according to search results, had a Croatian institution as a participant or coordinator, and downloaded the data. The second objection, stated also by other authors, is that is difficult to analyse the data in heterogeneous organisations, because the database often does not refer to the participating institution but the subunits such as faculty, department, laboratories, centres etc. Each organisation participating in FP7 is assigned a unique Participant Identification Code (PIC). The introduction of PIC did not solve this problem since in Croatia faculties are independent legal entities (see Vizek Vidović and Bjeliš, 2006) and many of them have their own PIC, regardless of the fact that the university also has a PIC. This problem was solved by manual revision and data correction. Some problems have arisen with data comparison of both databases (CORDIS and eCORDA), since the data in these databases slightly differ, although they should be identical. For example, the project "Energy Efficient Demo Multiresidential High Rise Building" is stated in eCORDA under the theme "Energy", and in the CORDIS database under the theme "Environment". Also, some projects can be found in one database but not in the other - for example, the project "Night-of-the-Lab-Out" was present, at the end of July 2013, in the CORDIS database but not in eCORDA, although its implementation started on May 1st 2013.

Based on the downloaded data the following analysis of Croatian participation in FP7 was made: (i) Analysis of institutions that participated in the FP7 programme; (ii) Analysis of participation according to specific programmes, (iii) Analysis of participation according to the funding scheme, (iv) Analysis of participation according to the coordinator organisations, and $(v)$ Comparison with selected post-transition countries.

\section{Results}

\section{Financial contribution}

In the introduction it was stated that Croatia has obligation of national contribution to FP7. Table 1 gives an overview of the Craotian National Contribution to FP7 and EU Financial Contribution to Croatian Participants (in million Euro). National contribution grows annually, and from 2,7 million Euro in 2007 it grew to 13 million Euro in 2013 and its total sum amounts to 49,4 million Euro, which is, on average, more than 7 million annually. EU financial contribution to Croatian participants was bigger than national contribution to FP7; annual amounts were between 7 and 12 million Euro and thus the total amount of EU financial contribution is 72 million Euro.

\section{Institutions that participated in the FP7}

Most of the Croatian participants in the FP7 are publicly funded R\&D institutions (universities and research institutes) and public bodies. The situation was similar in FP6, in which 107 out of 154 Croatian participants were from universities and research institutes (Mataković, 2011). In FP6 Croatian companies had high participation in some of the programmes. For example, in the "Life science, genomics and biotechnology for health" $47 \%$ of Croatian participants were companies (Ortega and Aguillo, 2010) which is not typical for a programme in which public research organisations are main participants (Gusmão, 2001). 
Table 1 represents Croatian national contribution to FP7, EU financial contribution to Croatian participants and ratio of EU contribution and national contribution. As in the first years of the Seventh Framework Programme national contribution was quite low, the ratio of EU contribution and national contribution was extremely good, especially in the first year of FP7 (2007), where the EU contribution was 3,3 times higher than the national contribution. In the following years this ratio varied and gradually decreased, and at the end of the whole programme EU contribution was only slightly higher than the national contribution. The ratio of total national contribution and total EU contribution is positive and for the first six and a half years is 1,46 . In other words, for every Euro of national contribution almost Euro and a half was withdrawn.

Table 1

Croatian National Contribution to FP7 and EU Financial Contribution to Croatian Participants (in million Euro)

\begin{tabular}{l|ccc}
\hline Year & $\begin{array}{c}\text { National } \\
\text { contribution }\end{array}$ & $\begin{array}{c}\text { EU financial } \\
\text { contribution }\end{array}$ & $\begin{array}{c}\text { Ratio of National Contribution to FP7 and } \\
\text { EU Financial Contribution to Croatian } \\
\text { Participants }\end{array}$ \\
\hline 2007 & 2,7 & 9,1 & 3,37 \\
2008 & 3,7 & 8,3 & 2,24 \\
2009 & 4,8 & 7,1 & 1,48 \\
2010 & 6,4 & 12,3 & 1,92 \\
2011 & 8,4 & 11 & 1,31 \\
$2012-2013$, June & 23,5 & 24,2 & 1,03 \\
\hline Total & 49,4 & 72 & 1,46 \\
\hline
\end{tabular}

Source: Memorandum of Understanding on the Association of Republic of Croatia to the FP7, https://webgate.ec.europa.eu/e-corda/

Table 2 represents participation by type of organisation: in FP7 there is evidently an increase of participants from the business sector (private for profit) - out of the total of 107 participants, 64 are small and medium-sized enterprises. Croatian branches of large multinational companies participated only in a small number of projects; for example, Ericsson Nikola Tesla had three participants or Croatian Telecom, which is in majority-owned by Deutsche Telekom, with only one participant.

Table 2

Participation by Type of Organisation

\begin{tabular}{|c|c|c|c|c|}
\hline \multirow[t]{2}{*}{ Type of Organisation } & \multicolumn{2}{|c|}{ Croatia } & \multicolumn{2}{|c|}{ FP7 total } \\
\hline & $\begin{array}{l}\text { Number of } \\
\text { Participants }\end{array}$ & $\ln \%$ & $\begin{array}{l}\text { Number of } \\
\text { Participants }\end{array}$ & $\ln \%$ \\
\hline Higher or secondary education & 104 & 33,12 & 37.958 & 38,21 \\
\hline Research organisations & 50 & 15,92 & 25.350 & 25,52 \\
\hline $\begin{array}{l}\text { Public body (excluding research and } \\
\text { education) }\end{array}$ & 56 & 17,83 & 4.718 & 4,75 \\
\hline Private for profit (excluding education) & 107 & 34,08 & 28.399 & 28,59 \\
\hline Other & 11 & 3,50 & 2.921 & 2,94 \\
\hline Total & 314 & 100 & 99.346 & 100 \\
\hline
\end{tabular}

Source: http://cordis.europa.eu/projects/, EC, 2013,100, calculations by author

According to a study from Finland, SMEs participate in the Framework programmes due to research funding while the large companies are mostly interested in participation because it opens them possibilities of new exchanges and informal contacts (Luukkonen, 2000). This is partly true for Croatia, but it should be also taken into account that for large multinational companies in Croatia research is not primary business because they are mainly oriented towards production, and the core technology is developed outside of Croatia. The total EU 
financial contribution to Croatia in July 2013 was 72 million euros. From that sum, university participants have withdrawn a total of 32,4 million and research institutes 11,2 million.

Universities in the EU are constantly increasing the share of revenues from the EU. Lately the importance of internationalisation of research grew up and also increased the importance of research networks, so participation in the Framework Programmes has become essential to European universities (Geuna, 1998). The situation in Croatia is somewhat different, and according to data about the number of participants in FP7 it can be concluded that not all universities recognise the importance of participation in the same way. Among university participants there are strong regional disproportions, since the largest number of university participants are from the University of Zagreb. The situation was similar in FP6, where out of 67 participants from universities, 52 were from the University of Zagreb (Mataković, 2011). In FP7 this ratio has somewhat decreased, but participation of other Croatian universities is still significantly lower.

As shown in table 3, the University of Zagreb has also the largest share in the EU financial contribution; significant financial resources (in relation to number of participants) were allocated to the University of Rijeka. The majority of these funds is from the School of Medicine since 6 out of 10 participants from the University of Rijeka are the School of Medicine members, and out of 5,04 million euros in total withdrawn by the University of Rijeka, more than 4,4 million are from the School of Medicine. The situation is similar in other European countries: for example, in Spain, the three most developed regions withdrew about $75 \%$ of the EU financial contribution to Spain in FP3 (Vence et al., 2000).

Table 3

University Participation

\begin{tabular}{lrr}
\hline University & $\begin{array}{c}\text { Number of } \\
\text { participants }\end{array}$ & $\begin{array}{c}\text { EU financial contribution } \\
\text { (in Euro) }\end{array}$ \\
\hline University of Dubrovnik & 1 & 4.000 \\
Josip Juraj Strossmayer University of & 0 & 0 \\
Osijek & 0 & 0 \\
Juraj Dobrila University of Pula & 10 & 5.048 .000 \\
University of Rijeka & 12 & 779.000 \\
University of Split & 1 & 80.000 \\
University of Zadar & 80 & 26.525 .000 \\
University of Zagreb & 104 & 32.436 .000 \\
\hline Total & &
\end{tabular}

Source: http://cordis.europa.eu/projects/, eCORDA

Table 4

Top 5 Research Institutes and Top 5 Business Sector Participants

\begin{tabular}{|c|c|c|}
\hline & Participant & Number of Participants \\
\hline \multirow{6}{*}{ 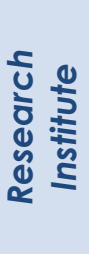 } & Ruder Boskovic Institute & 26 \\
\hline & Institute of Oceanography and Fisheries & 5 \\
\hline & Energy Institute "Hrvoje Pozar" & 3 \\
\hline & Institut drustvenih znanosti Ivo Pilar & 2 \\
\hline & Institut za medicinska istrazivanja i medicinu rada & 2 \\
\hline & Institut za medunarodne odnose & 2 \\
\hline \multirow{7}{*}{ 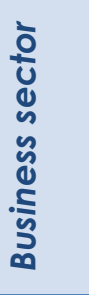 } & Novamina centar inovativnih tehnologija d.o.o. & 18 \\
\hline & Alveus L.L.C. & 5 \\
\hline & Emergo d.o.o. & 5 \\
\hline & Brodarski institut d.o.o. & 4 \\
\hline & Genos d.o.o. za vjestacenje i analizu & 4 \\
\hline & Inetec-institut za nuklearnu tehnologiju & 4 \\
\hline & Uljanik brodogradiliste & 4 \\
\hline
\end{tabular}


A similar regional disproportion is visible in the participation of research institutes (see Table 4). In FP7 there are 43 research institutes participants, most of them from the Ruder Boskovic Institute. Ruder Boskovic Institute is the largest Croatian research institute with more than 550 researchers, however, its dominance in FP7 participation and also modest participation of other institutes cannot be explained only by its size. The situation is even more serious having in mind that out of 11,18 million Euro of the EU financial contribution withdrawn by research institutes, over 10 million are from the Ruder Boskovic Institute (Smith, 2013). From the business sector participants, most (18) participants are from Novamina SME.

\section{Participation according to specific programmes}

Seventh Framework Programme is implemented through four specific programmes: Cooperation, Ideas, People and Capacities. Cooperation programme funds projects in which research and other activities are implemented by consortia of participants from various, mostly European, countries. This specific programme is the core of FP7, with 32 of 50 billion euros (64\%) of total Seventh Framework Programme. The Ideas programme finances research in new areas of science, the People programme supports mobility and Capacities programme funds research capacities strengthening. Cooperation programme is divided into 10 themes, which are defined according to different areas of science. As shown in table 5, the majority of grants signed with Croatian participants are in Cooperation programme in themes ICT, Food and Agriculture, Environment and Transport.

Table 5

Signed Grants by Specific Programme

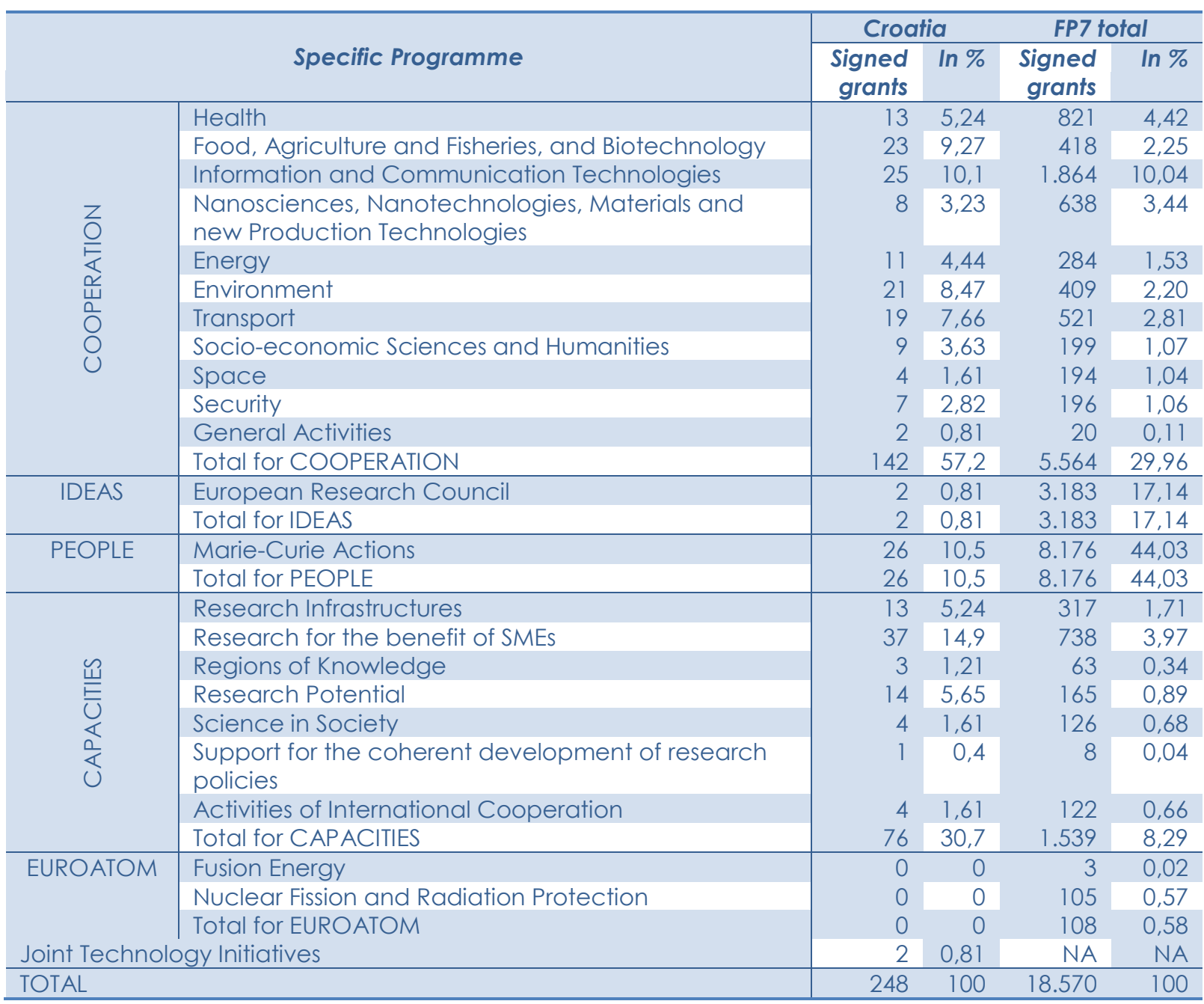

Source: http://cordis.europa.eu/projects/, EC, 2013, 42, calculations by author 
The number of projects in Capacities programme was above half of the number of Cooperation projects. In relation to the whole FP7, Croatia has significantly fewer grants signed in People programme and the Ideas programme which, due to the low success rate and generous funding, becomes a sort of Champions League of European science.

With the exception of the University of Zagreb, universities participation in Cooperation programme (see Table 6) was rather modest. The University of Rijeka had only two participants in the Cooperation programme and the University of Split five. The University of Zagreb had 50 participants, most of them in ICT, Food and Agriculture, Energy and Environment themes.

Table 6

Signed Grants in Specific Programmes in which Croatian Universities participated

\begin{tabular}{|c|c|c|c|c|c|c|}
\hline \multicolumn{2}{|c|}{ Specific programme } & $\begin{array}{l}\text { University } \\
\text { of } \\
\text { Dubrovnik }\end{array}$ & $\begin{array}{l}\text { University } \\
\text { of Rijeka }\end{array}$ & $\begin{array}{l}\text { University } \\
\text { of Split }\end{array}$ & $\begin{array}{l}\text { University } \\
\text { of Zadar }\end{array}$ & $\begin{array}{l}\text { University } \\
\text { of } \\
\text { Zagreb }\end{array}$ \\
\hline \multirow{10}{*}{ 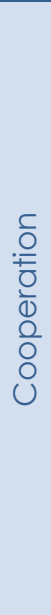 } & Health & 0 & 1 & 1 & 0 & 6 \\
\hline & $\begin{array}{l}\text { Food, Agriculture and Fisheries, } \\
\text { Biotechnology }\end{array}$ & 0 & 0 & 0 & 1 & 9 \\
\hline & $\begin{array}{l}\text { Information \& communication } \\
\text { technologies }\end{array}$ & 0 & 0 & 1 & 0 & 12 \\
\hline & $\begin{array}{l}\text { Nanosciences, nanotechnologies, } \\
\text { materials \& new production } \\
\text { technologies }\end{array}$ & 0 & 0 & 0 & 0 & 2 \\
\hline & Energy & 0 & 0 & 0 & 0 & 5 \\
\hline & $\begin{array}{l}\text { Environment (including Climate } \\
\text { Change) }\end{array}$ & 0 & 0 & 3 & 0 & 5 \\
\hline & Transport (including aeronautics) & 0 & 1 & 0 & 0 & 3 \\
\hline & $\begin{array}{l}\text { Socio-economic Sciences and the } \\
\text { Humanities }\end{array}$ & 0 & 0 & 0 & 0 & 3 \\
\hline & Space & 0 & 0 & 0 & 0 & 3 \\
\hline & Security & 0 & 0 & 0 & 0 & 2 \\
\hline \multicolumn{2}{|c|}{ Ideas } & 0 & 1 & 0 & 0 & 1 \\
\hline \multicolumn{2}{|c|}{ People } & 0 & 4 & 4 & 0 & 8 \\
\hline \multicolumn{2}{|c|}{ Capacities } & 1 & 3 & 3 & 0 & 23 \\
\hline
\end{tabular}

Source: http://cordis.europa.eu/projects/

Participation according to the funding scheme

Seventh Framework Programme has various funding schemes. There are "standard" research projects called "collaborative projects", and given the size (number of participants and financial support) can be larger (large-scale integrating project) or smaller (small or mediumscale focused research project). Table 7 represents participants by funding instruments. In "collaborative projects (CP) and combination of CP and CSA" funding scheme, out of 142 participants, 17 were participants in "combination of CP and CSA and 46 in "small or medium-scale focused research projects".

Table 7

Participants by Funding Instruments

\begin{tabular}{|c|c|c|c|c|}
\hline \multirow[t]{2}{*}{ Funding instrument } & \multicolumn{2}{|l|}{ Croatia } & \multicolumn{2}{|c|}{ FP7 total } \\
\hline & $\begin{array}{l}\text { Number of } \\
\text { Participants }\end{array}$ & $\ln \%$ & $\begin{array}{l}\text { Number of } \\
\text { Participants }\end{array}$ & $\ln \%$ \\
\hline $\begin{array}{l}\text { Collaborative projects (CP) and combination of } \\
\mathrm{CP} \text { and CSA }\end{array}$ & 142 & 45,2 & 58.969 & 59,4 \\
\hline Coordination and support actions (CSA) & 94 & 29,9 & 15.676 & 15,8 \\
\hline Networks of Excellence & 1 & 0,3 & 1.036 & 1,0 \\
\hline ERC Grant & 2 & 0,6 & 3.669 & 3,7 \\
\hline Marie Curie actions & 19 & 6,1 & 13.236 & 13,3 \\
\hline Research for the benefit of specific groupings & 56 & 17,8 & 6.760 & 6,8 \\
\hline Total & 314 & 100 & 99.346 & 100 \\
\hline
\end{tabular}

Source: http://cordis.europa.eu/projects/, EC, 2013, 99, calculations by author 
The number of Croatian participants was quite high in the "coordination and support actions" funding scheme, in which research is not funded, but various activities related to research (networking, exchanges, studies, conferences, etc.). In relation to FP7 total, Croatia has more participants than total FP7 in non-research funding instrument "coordination and support actions" and small size research funding instrument "research for the benefit of specific groupings", e.g. research for the benefit of SMEs. Croatian participants have significantly smaller participation than rest of FP7 in "ERC Grant" and "Marie Curie actions" funding instruments.

\section{Participation according to the coordinator organisations}

Table 8 represents top 10 coordinator organisations in projects with Croatian participants. Most projects with Croatian participants were coordinated by Deutsches Zentrum fuer Luft und Raumfahrt (national centre for aerospace, energy and transportation research of the Federal Republic of Germany), SINTEF (Norwegian broadly based, multidisciplinary research concern and the largest independent research organisation in Scandinavia) and Universitat Autonoma de Barcelona. Most coordinators of projects with Croatian participants were from the United Kingdom (31), Germany (25), Italy (20), Spain (19) and France (17), which is not surprising since these are the countries with the largest number of participants (top 5) in FP7 (EC, 2013).

Croatian participants were coordinators of only 31 projects out of 248 (12\%). This result is even worse if we have in mind that most of the projects coordinated by Croatian participants are projects without international consortium, and the coordinators are mostly the only participants.

Table 8

Top 10 coordinator Organisations in Projects with Croatian Participants

\begin{tabular}{lr}
\hline Coordinator organisations & Number of projects \\
\hline Deutsches Zentrum fuer Luft - und Raumfahrt & 4 \\
Stiftelsen Sintef & 4 \\
Universitat autonoma de Barcelona & 4 \\
Agenzia per la promozione della ricerca Europea & 3 \\
Aristotelio Panepistimio Thessalonikis & 3 \\
Consiglio nazionale delle ricerche & 3 \\
The University of Manchester & 3 \\
Universitaetsmedizin der Johannes Gutenberg-Universitaet Mainz & 3 \\
\hline Zentrum fuer soziale Innovation & \\
\hline
\end{tabular}

Source: http://cordis.europa.eu/projects/

\section{Comparison with selected post-transition countries}

The overall Croatia success in the Seventh Framework Programme could be better assessed if is compared with the countries of Central and Eastern Europe (CEE). Twelve post-transition countries are chosen for comparison - 7 of them are members of the EU (Bulgaria, Estonia, Latvia, Lithuania, Romania, Slovakia and Slovenia) and 5 of them are candidate countries for the EU membership (Albania, Bosnia and Herzegovina, Macedonia, Montenegro and Serbia). The above mentioned candidates countries are the so called Western Balkan countries.

Table 9 shows number of participants for FP7 calls in 2007 - 2011 and Table 10 shows EU Financial Contribution for FP7 calls in 2007 - 201 1. In first five years of FP7 Croatia was the most successful of all Western Balkans countries, which is not surprising because Croatia is by population much bigger than Albania, Bosnia, Montenegro and Macedonia. Croatia has more participants (Table 9) and larger EU financial contribution (Table 10) than Serbia, the only country in the Western Balkans which is by population bigger than Croatia. Compared to the countries of the CEE region Croatia has a similar number of participants as Lithuania and the EU financial contribution as Slovakia. To avoid the impact of the country size and to get a standardised data, the number of participants and the EU financial contribution is combined with the number of full time equivalent (FTE) researchers. This comparison showed that 
Croatia in number of participants is similar to Lithuania and Romania and in the EU financial contribution is better than Bulgaria, Latvia, Lithuania, Romania and Slovakia.

Figure 1

Researchers total (FTE), all Sectors in 2011 (Selected CEE Countries)

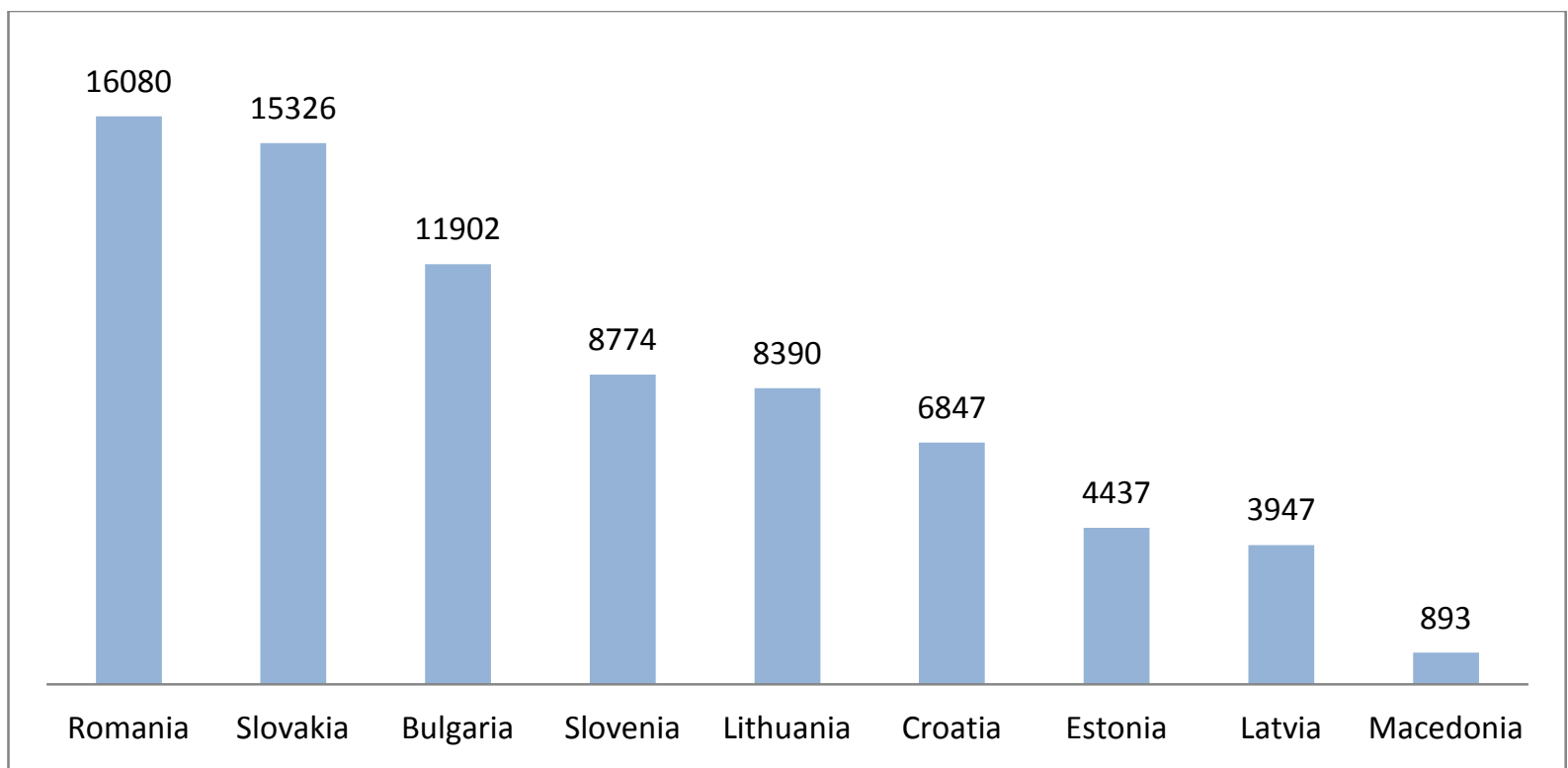

Source:

http://epp.eurostat.ec.europa.eu/tgm/table.do?tab=table\&init=1 \&plugin=1 \&language=en \& pcode=tsc00004.

Data for Albania, Bosnia and Herzegovina, Montenegro and Serbia is not available. In case of Macedonia the 2009 data was used.

Table 9

Number of Participants for FP7 calls in 2007 - 2011

\begin{tabular}{|c|c|c|c|c|c|c|c|}
\hline \multirow{2}{*}{ Country } & \multicolumn{7}{|c|}{ Number of participants } \\
\hline & 2007 & 2008 & 2009 & 2010 & 2011 & Total & $\begin{array}{l}\text { Per FTE } \\
\text { researcher }\end{array}$ \\
\hline Albania & 7 & 6 & 10 & 7 & 2 & 32 & NA \\
\hline $\begin{array}{l}\text { Bosnia and } \\
\text { Herzegovina }\end{array}$ & 7 & 5 & 6 & 8 & 4 & 30 & NA \\
\hline Bulgaria & 161 & 94 & 92 & 90 & 106 & 543 & 0,0456 \\
\hline Croatia & 68 & 39 & 40 & 76 & 63 & 286 & 0,0418 \\
\hline Estonia & 108 & 68 & 70 & 62 & 59 & 367 & 0,0827 \\
\hline Latvia & 58 & 35 & 40 & 39 & 44 & 216 & 0,0547 \\
\hline Lithuania & 71 & 61 & 52 & 59 & 61 & 304 & 0,0362 \\
\hline Macedonia & 20 & 17 & 10 & 13 & 18 & 78 & 0,0873 \\
\hline Montenegro & 8 & 10 & 3 & 9 & 5 & 35 & NA \\
\hline Romania & 234 & 132 & 138 & 120 & 144 & 768 & 0,0478 \\
\hline Serbia & 50 & 31 & 35 & 51 & 49 & 216 & NA \\
\hline Slovakia & 105 & 61 & 72 & 57 & 67 & 362 & 0,0236 \\
\hline Slovenia & 179 & 95 & 123 & 96 & 131 & 624 & 0,0711 \\
\hline
\end{tabular}

Source: EC 2013, 96, calculations by author 
Table 10

EU Financial Contribution (in million Euro) for FP7 calls in 2007 - 2011

\begin{tabular}{|c|c|c|c|c|c|c|c|}
\hline \multirow[t]{2}{*}{ Country } & \multicolumn{7}{|c|}{ EU financial contribution } \\
\hline & 2007 & 2008 & 2009 & 2010 & 2011 & Total & $\begin{array}{c}\text { Per FTE } \\
\text { researcher }\end{array}$ \\
\hline Albania & 0,4 & 0,2 & 0,6 & 0,2 & 0,2 & 1,6 & NA \\
\hline $\begin{array}{l}\text { Bosnia and } \\
\text { Herzegovina }\end{array}$ & 0,6 & 0,2 & 0,3 & 0,6 & 0,7 & 2,4 & NA \\
\hline Bulgaria & 18,7 & 11,8 & 14,8 & 13,2 & 13,3 & 71,8 & 0,0060 \\
\hline Croatia & 9,1 & 8,3 & 7,1 & 12,3 & 11 & 47,8 & 0,0070 \\
\hline Estonia & 19,5 & 10,5 & 11,3 & 10,2 & 6,7 & 58,2 & 0,0131 \\
\hline Latvia & 7,8 & 3,1 & 3,3 & 6,6 & 4,5 & 25,3 & 0,0064 \\
\hline Lithuania & 9,2 & 9,2 & 8,1 & 5 & 6,1 & 37,6 & 0,0045 \\
\hline Macedonia & 2,4 & 3,4 & 1,4 & 0,6 & 1,9 & 9,7 & 0,0109 \\
\hline Montenegro & 0,4 & 0,5 & 1,3 & 0,3 & 0,1 & 2,6 & NA \\
\hline Romania & 30,3 & 18 & 23,5 & 15,5 & 19 & 106,3 & 0,0066 \\
\hline Serbia & 11,3 & 4,4 & 10,2 & 5,8 & 4,2 & 35,9 & NA \\
\hline Slovakia & 14,9 & 7,1 & 9,4 & 8,1 & 15,7 & 55,2 & 0,0036 \\
\hline Slovenia & 33,5 & 11,8 & 18,6 & 19,6 & 23,2 & 106,7 & 0,0122 \\
\hline
\end{tabular}

Source: EC 2013,96, calculations by author

Table 11 shows success rates of applicants for FP7 calls concluded in 2007 - 2012. In this table are compared best EU-15 Countries (EU-15 are first 15 countries which become EU member states - the last of them were admitted to EU membership in 1995; almost all of EU-15 countries are economically most developed countries of EU) and selected CEE countries. The success rate of most CEE countries is lower than the success rate of the EU-15 countries. Most EU-15 countries have a success rate in FP7 higher than $20 \%$ while in selected CEE countries success rate higher than $20 \%$ is only in Montenegro, Latvia, Estonia and Lithuania. If we exclude Montenegro from the comparison because Montenegro had only 35 participants in the first 5 years of FP7 and therefore cannot be a reliable example, it can be concluded that Baltic countries have the highest success rate, which is in line with the average EU success rate $21,7 \%$ (EC, 2013). Of all western Balkan countries Croatia has a highest success rate, and a bit higher than Slovenia and Romania, but it is still below the EU average.

Table 11

Success Rates of Applicants for FP7 Calls concluded in 2007 - 2012 - top EU-15 Countries and Selected CEE Countries

\begin{tabular}{|c|c|c|c|}
\hline \multicolumn{2}{|c|}{ EU-15 countries } & \multicolumn{2}{|c|}{ Selected CEE countries } \\
\hline County & Success rate & County & Success rate \\
\hline Belgium & $26,2 \%$ & Montenegro & $23,5 \%$ \\
\hline Netherlands & $25,4 \%$ & Latvia & $21,7 \%$ \\
\hline France & $25,0 \%$ & Estonia & $21,2 \%$ \\
\hline Denmark & $24,2 \%$ & Lithuania & $20,1 \%$ \\
\hline Germany & $23,8 \%$ & Slovakia & $18,3 \%$ \\
\hline Sweden & $23,5 \%$ & Croatia & $17,1 \%$ \\
\hline United Kingdom & $23,2 \%$ & Serbia & $16,5 \%$ \\
\hline Austria & $21,9 \%$ & Bulgaria & $16,4 \%$ \\
\hline Ireland & $21,9 \%$ & Macedonia & $16,4 \%$ \\
\hline Finland & $21,5 \%$ & Slovenia & $15,9 \%$ \\
\hline Spain & $19,7 \%$ & Romania & $14,6 \%$ \\
\hline Luxembourg & $19,2 \%$ & Albania & $13,9 \%$ \\
\hline Portugal & $18,7 \%$ & Bosnia and Herzegovina & $11,8 \%$ \\
\hline
\end{tabular}

Source: EC, 2013, 96 


\section{Discussion}

In order to evaluate Croatian participation in the Seventh Framework Programme more proficiently, two analyses will be conducted: the first being participation analysis based on the results presented in the previous section of the paper, and the other being the analysis of external conditions for the programme participation. With external conditions analysis the paper will try to give explanation of the results, i.e. the participation analysis.

\section{Evaluation of the Croatian institutions' participation in Seventh Framework Programme}

Participation of Croatian institutions in the Seventh Framework Programme has the following features, which will be further explained below:

- The positive rate of national contribution and EU financial contribution;

- Unequal regional distribution of participants;

- Small number of projects coordinated by Croatian participants;

- Low success rate and

- Small number of participants in large research projects.

The positive rate of national contribution and EU financial contribution

Full membership in the Framework Programmes includes the requirement of national financial contribution. National contribution is calculated on the basis of gross domestic product. At the start of this paper it was pointed out that Croatian participation in FP6 was financially successful as its national contribution totalled 6,4 million Euro and EU financial contribution was 16,2 million Euro. Having only finances in mind, participation in the Seventh Framework Programme is also successful, as the total national contribution amounts to 48,9 million Euro and that at the time of writing this article (July, 2013) EU financial contribution amounts to 72 million Euro.

However, to get a more realistic picture, the result should be compared with the countries that are to some extent similar to Croatia, either by geographical location, size, or the past (post-transitional countries). When EU financial contribution is divided by the number of FTE researchers in every country, it is evident that EU financial contribution in Croatia counts 7.000 Euro per FTE researcher, which is a better result than in Bulgaria, Latvia, Lithuania, Slovakia and Romania. However, it should be taken into account that, for example, in Estonia and in Slovenia EU financial contribution counts more than 12.000 euros per FTE researcher, which is almost twice the amount in Croatia.

\section{Unequal regional distribution of participants}

A strong regional disproportion is evident in FP7 grants signed by organisations with headquarters in Zagreb compared to organisations from other parts of Croatia; organisations in the Zagreb area are included in $80 \%$ of FP7 projects with Croatian participants (MZOS, 2013, 6). In addition to a general level of all participants, this disproportion is also evident at the level of academic participants: out of 104 university participants, 80 are from the University of Zagreb and out of 43 participants from research institutes, 26 are from the Ruder Boskovic Institute. Disproportion is also evident in the EU financial contribution: out of 32,4 million Euro of EU financial contribution to university participants, 26,5 million are from the University of Zagreb. Out of 11,18 million Euro of EU financial contribution to research institutes, over 10,6 million are from the Ruder Boskovic Institute.

The four smaller universities in Croatia (Dubrovnik, Osijek, Pula and Zadar) had a total of only two participants in FP7 projects, even though they employ 1.737,6 FTE researchers (the University of Dubrovnik has 147,7 FTE researchers, The University of Osijek 1.045,7, the University of Pula 164,0 and the University of Zadar has 380,2 FTE researchers). Low participation of these four universities can be explained in three ways. The first is that Universities of Dubrovnik, Pula and Zadar are more teaching than research universities and scientists from these universities, given their level of research experience and/or technical equipment for research generally does not have the research quality necessary to be invited to (successful) Framework Programme consortia. Another reason is that these universities are mainly concerned with 
teaching assignments and only in a small extent with research and that is reason why most of their employees are not interested in participating in FP projects. Research in these universities is still largely funded from the state budget, but within these funds a general downward trend is evident - their situation is similar to many universities in Central and Eastern Europe (Jóźwiak, 2002). The third possible explanation is the lack of information about the Seventh Framework Programme, as the majority of info days and other forms of informing potential participants took place in Zagreb. This explanation could be only partly taken into account considering a large amount of information available online and in print. For universities without, or with a small number of participants in FP7, the number of participants is not likely to increase significantly in the future. In a study conducted at a number of universities across Europe it was found out that the lack of experience in the application of projects and competition for funds has a negative effect on the propensity to participate in cooperative research projects (Geuna, 1998) so they are in some sort of "vicious circle" with no way out, and they could easily fall into the "low R \& D trap". The "low R \& D trap" indicates low participation in European programmes, and low participation then has the consequence of increasing the difference in relation to the more developed regions (Vence et al., 2000).

\section{Low number of projects coordinated by Croatian participants}

Out of 248 projects involving Croatian participants, only 31 were coordinated by them. Most of the projects coordinated by Croatian participants are projects for which the rules of the call do not require international cooperation, so the coordinator in these projects is also the only participant. Projects where the Croatian coordinator is the only participant are amounted on 29,29 million Euro out of the total of 72 million Euro i.e. $40 \%$ of EU financial contribution. Of these 29,29 million, 22,12 million Euro are from Regional potential programme (REGPOT).

The projects under the Regional potential programme are not collaborative research projects (which is one of the fundamental objectives of ERA), but their goal is to strengthen the research potential through knowledge transfer and acquisition of equipment. Only 4 of the 31 projects that are coordinated by Croatian partners are projects that implement collaborative research with international partners: three are from the "Research for the benefit of SMEs" programme and one from the "Health" programme. These facts show that it is difficult to enter the circle of coordinators since, to some extent, coordinators of FP projects have already emerged. Data from the Third and Fourth Framework Programmes shows an interesting trend: the organisations that had been project coordinators have also participated in a much higher number of projects than organisations that were the only partners in projects. Although the average number of projects per organisation was 2,79, about $15 \%$ of all coordinators have participated in more than 10 projects, either as a coordinator or as a partner. Furthermore, $46 \%$ of the coordinators were the coordinator of three or more projects (Breschi et al., 2004).

While discussing the number of Croatian participants, the low number of national project partners should also be noted. In FP6, 154 Croatian participants participated in 134 projects, which is an average of 1,14 Croatian participants per project. In FP7 314 participants participated in 248 projects, which amounts to 1,26 Croatian participants per project. For comparison, out of all projects in the Fourth framework programme (1994-1998) that had at least one French participant, $45 \%$ actually had more than one French participants (Gusmão, 2001). Low number of national project partners can be explained in two ways: first explanation is strong tendency to search for international partners, where collaboration with them will lead to knowledge transfer.

Another explanation for such weak national cooperation may be limited national resources, where, for example, in a country, there is only one strong research center in a particular subject area (Rivera León et al., 2010). Both explanations can be applied to Croatia, but it should be taken into account that there are significant differences between various scientific fields. So far in Croatia trends from the rest of Europe where research programs implemented by the EU encourage the emergence of national networks for participation in the EU projects (Gusmão, 2001) have not emerged to a larger extent. 


\section{Low success rate}

One indicator of quality of Framework Programmes participation is the success rate. The success rate for EU member states varies from $26,2 \%$ in Belgium to $14,6 \%$ in Romania. Croatian success rate in the first six years of the Seventh Framework Programme was 17,1\%, which is lower than the average rate of success for the EU Member States, which amounts to $21,7 \%$. Lower success rate than Croatia only have Bulgaria, Greece, Slovenia, Cyprus and Romania (EC, 2013). Such low success rate of Croatian participants can be explained in two ways: a) they participate in consortia led by lower quality coordinator or b) they participate in consortia led by coordinator less experienced in project proposal writing.

In each project proposal in FP7, a track record of the coordinator and partners should be specified, which describes their experience in the scientific field for which the project is applied, previous projects (in particular experience in coordinating FP projects) and published papers. This is not the only criterion for a successful application, since high-quality project activities also have to be developed and convincingly described, but to some extent, it affects the successfulness of the project application. High quality coordinator will choose high quality consortia, and Croatian participants are not always good enough to be invited to high quality consortia.

Other explanation is quality of project proposal: creating successful proposals is a complicated process that involves a variety of skills, from choosing the right theme of the project, recognising the right "wording" to financial knowledge, planning the project budget but also lobbying and solicitations (Rodríguez et al., 2013). This experience is gained over years and beginners (i.e. low quality coordinators) generally will not be successful in highly competitive programs such as FP.

\section{Small number of participants in large research projects}

Projects in the Seventh Framework Programme are implemented under various financing schemes. The simplest classification of financing schemes can be done by dividing projects to research or non-research projects, i.e. those which do not fund the research itself but a variety of activities related to science and research, such as networking, exchanges and conferences (so-called "coordination and support actions"). Research projects ("collaborative projects") may be bigger in context of number of participants, financial value and duration ("large-scale integrating project") or smaller ("small or medium-scale focused research project").

The highest number of Croatian participants participated in non-research projects or in small research projects: almost $30 \%$ participated in non-research "coordination and support actions", $18 \%$ of participants participated in relatively small "research for benefit of SME" scheme and $15 \%$ in smaller research projects ("small or medium-scale focused research projects"). In large "collaborative projects", which have higher significance, participated 79 out of the 314 participants. In the most prestigious, financially strong "ERC grants" Croatia had only two participants, and both projects began at the end of the Seventh Framework Programme.

\section{External conditions influencing Croatian institutions' participation in FP7}

Furtherly, external conditions will be analysed, i.e. those on which the participants in FP7 could not influence, but which significantly influenced the number and quality of participation in FP7. External conditions have shown, unfortunately, unfavourable for Croatian participants in FP7 and have, instead of encouraging participation, discouraged potential participants and made implementation of already implemented projects more complicated. External conditions which will be further analysed are:

- Legal framework;

- Administrative support;

- Advancement in scientific careers and

- Rewarding of applicants.

Legal framework. Administrative and financial implementation of projects in the Seventh Framework Programme is in one part carried out in accordance with the rules of the Framework Programme and the other part according to national legislation or usual practice 
of the participating institution. Until now, in Croatia many situations come up where it was not entirely clear how to conduct project implementation, since the national legislation did not embrace issues which came up during the projects implementation. Responses of national authorities, particularly tax administration, who were supposed to ensure legal certainty and provide guidance for the implementation of projects, were extremely slow and incomplete. For example, the interpretation regarding VAT exemption in FP7 projects was issued by tax administration in November 2008, although the implementation of FP7 projects started in 2007. Likewise, the interpretation of the treatment of labour on FP7 projects for people permanently employed in public research organisations was issued in 2011 , although in the meantime some of the earlier starting FP7 projects were already completed. Legal uncertainty is still ongoing - for example, at the time of writing, it is still unclear whether FP7 projects, for which the grant agreements were signed after June 26, 2013 when a new Law on VAT came into effect and in which FP7 programme is not mentioned, will be exempt from paying $V A T$ on project expenditures.

Administrative support. Application and projects implementation under the Framework Programmes, considering their complexity and extensiveness, aside from scientific and technical knowledge require also a significant level of administrative skills. Support for application but also for administration of FP7 projects is given by national contact points (NCP). All countries participating in the Framework Programmes have National contact points - they are usually specialised for a particular programme or theme of the Framework Programme and are mainly employed by the Ministry of Science and similar institutions. First Croatian NCPs were employed in 2001 at the Ministry of Science. In 2007, five NCPs were transferred from the Ministry of Science to Croatian Institute of Technology, a public limited liability company, which was established by the Croatian Government in 2006.

Number of NCPs had over time increased to eight. Two people working at the Ministry of Science and one employed at the Croatian State Institute for Radiological and Nuclear Safety should be added to this number. In 2013 it was decided that the NCP network will be again transferred: this time from the Croatian Institute of Technology to the Agency for Mobility and EU programs; up to that moment in the Agency for mobility were employed only NCPs for the People programme. Only two of the eight NCPs moved to the Agency while the remaining NCPs became employees of Business Innovation Croatian Agency or were employed at other positions, thus a significant part of the knowledge and experience of the NCPs was lost. Most of the NCPs were hired as young people, mostly without experience in project management and the Framework Programmes. During the several years working as NCPs they participated in intensive trainings and gained valuable firsthand experience in the implementation of FP7 projects. Now their knowledge and experience is lost, since the newly hired NCPs at the Agency for Mobility are mostly new people without or with little experience in project management.

Organisations, mostly academic, involved in a high number of FP and other EU projects established offices and hired people to administer projects. They are mainly paid from project funds or their own resources. Such offices are functioning successfully at large faculties or research institutes, but the smaller institutions, which are involved in a small number of projects or do not have the sufficient funds to employ project managers, are in a complex situation. At such institutions researchers who mostly work on research issues in FP7 projects are forced to manage also the administrative part of projects implementation. Administrative work in FP7 is time consuming and can easily discourage researchers from future participation in FP projects.

Advancement in scientific careers. Since the volume of research work in FP projects is comprehensive and administration is extensive and complicated, only a small number of Croatian scientists is deciding to participate in Framework Programmes. To motivate members of the Croatian academic community to participate in the Framework Programmes and also in Horizon 2020, it is necessary to set participation in these programmes as a condition for academic advancement, and thus facilitate advancement of those who participate in Framework Programmes. On the other hand, generally speaking, participation in FP projects leads to internationalisation of Croatian science system and to international recognition of Croatian scientists and their work. All these facts are, however, not taken into account by the 
legislator although it was stated in 2008 in the Action plan 2008 - 2010 (MZOŠ, 2008, 10) that the participation in FP7 projects "will be considered in the evaluation of scientists and their academic advancement and provide a corresponding reduction in teaching load in order to encourage a growing number of researchers to propose FP7 projects". Regulation on the requirements for academic advancement (Official gazette, 26/2013) adopted in February 2013 defined conditions for academic advancement, but participation in international projects is defined as a condition for academic advancement only for scientists in Engineering. Moreover, participation in international projects is described in a general and vague way, so it is not clear whether the term "project" refers to projects such as FP projects or is it meant to refer to architectural, urbanism or similar projects. As the Regulation was repealed by the Constitutional Court in July 2013, we can only hope that participation in international projects will be included in the new Regulation.

Rewarding of applicants. In most European countries, participants in the Framework Programmes receive some form of financial incentive. Since projects in the Framework Programme consist mainly of international consortia, it is difficult to assess the workload of individual participants during preparation of the project proposal, and accordingly, reward it appropriately. Likewise, it is difficult to estimate the amount of expenses of participants during the application phase since they are different for each project. For projects coordinated by a Croatian institution the situation is much clearer - the successful applicant should be, in any case, financially rewarded. Ministry of Science used to financially reward successfully evaluated FP7 proposals, regardless of whether they were financed or not, with up to 2.500 Euro. In September 2008, this amount was increased, but also a gradation was made in the amount of financial support depending on whether the participant was partner or coordinator of the project. In March 2010, this financial reward was abolished. In the Action plan 2013 - 2015 the reintroduction of the financial reward was announced (MZOS, 2013, 13), however, a deadline is not specified, nor the possible level of support. It could be presumed that this external condition was of smallest importance to Croatian participants; participants took part in preparation the project applications because they wanted to participate in the projects, regardless of whether they will be financially rewarded by the Croatian government.

Proposed actions with the goal to increase Croatian institutions' participation in future European research programmes

Rivera León et al. (2010) in report on the participation of the of Southeast Europe countries in the EU research programmes gave a brief but very succinct recommendation, which may refer to Croatia, but also to all the other countries in the region: "there is a clear need for a concerted investment in research and innovation infrastructure and in the training and reskilling of scientists, technicians and engineers working in public, higher education and private sectors" (Rivera León et al., 2010).

Tasks and objectives from Croatian Action plan to raise the absorption capacity for the participation in the Framework Programmes 2013 - 2015 (MZOS, 2013) are less focused on investments in equipment and more on investment in people:

- Strengthening the competence and quality of administrative support both on the national and institutional levels;

- Stimulating and financially rewarding the best applicants;

- Linking scientific careers and advancement in science with parameters of coordination and participation in international competitive projects.

At first glance these measures sound simple, but their implementation is complicated and expensive, and in some cases politically sensitive. Since both measures and tasks stated in the Action plan 2008 - 2010 have not been fully implemented, it could be presumed that these proposed measures will remain only on a wish list.

In the report on the participation of EU Member States from CEE in FP7 (Rauch and SommerUlrich, 2012) are given various recommendations for strengthening FP participation, and the following recommendations are fully applicable to Croatia: (i) Vigorous support for FP participation as coordinator; (ii) Better integration of National Contact Points; and (iii) Strengthen lobbying. 


\section{Conclusions}

\section{Summary of results}

The aim of this study is to assess Croatian participation in FP7 through the analysis of participation and external conditions that affected the participation. Croatian participants from academic community (universities and the research organisations) are less represented in FP7 than it is FP7 average, but above-average representation is evident in public bodies. Specific programmes in which Croatia lags heavily by signed grants in relation to the FP7 average are the People programme and particularly ldeas programme. Funding shemes in which Croatian participants were more present than FP7 average are non-research scheme "coordination and support actions" and relatively small scheme "research for the benefit of SMEs", while participation in major research projects is lower than in FP7 average.

It is difficult to evaluate the success of Croatian participation in FP7 without comparison with other countries in the region. Comparison with other CEE countries, per FTE researcher, showed that in number of participants Croatia is similar to Bulgaria and Romania and in the EU financial contribution it is better than Bulgaria, Latvia, Lithuania, Romania and Slovakia. If we compare Croatian success rate with other CEE countries it can be concluded that Croatia has the highest success rate of all Western Balkans countries and a bit higher than Slovenia and Romania, but still below the EU average.

\section{Possible reasons for the level of Croatian organisations' participation in FP7}

It should be taken into account that external conditions have not been favourable to Croatian participants and that they often complicated the implementation of projects. Croatian legal framework in many situations proved vague and incomplete and governmental bodies that are supposed to give guidelines to FP7 participants have generally been slow in their responses. Administrative support supposed to be provided by the Ministry of Science often proved unsuccessful - the entire NCP network was shifted several times in a few years between different institutions. Neither the rewarding system was much better participation in FP7 is not taken into account in the advancements of the scientific career nor financial rewards. If the help and support to participants provided by national authorities have been better, it could be expected that Croatian participation in FP7 and the EU financial contribution would be higher. Therefore, improvement of external conditions should be a part of future Croatian research policies.

\section{Managerial implications}

Strengthening of legal framework is the most important prerequisite for future successful participation in Horizon 2020 and other EU research programmes. Croatian participants in FP7 were often, beside the research, dealing with legal issues due to the lack of legislation, to address the issues produced through the implementation of FP7 projects. Also, it is extremely important that researchers perform only research and not also projects administration - this requires well educated and trained administration staff. Furthermore, participants in future projects, especially coordinators, should be financially rewarded. Unfortunately, the academic community is still not yet fully aware the value of coordinator's role but also a participant's role in FP projects. Consequently, has not been regulated that participation in the Framework Programmes and in upcoming Horizon 2020 should be one of the conditions for scientific advancement. Apart from investment in people, it is also necessary to invest in research infrastructure, so that future Croatian participants could be equally equipped as their partners abroad. Failure to meet these basic recommendations, no matter if they require financial investment, will inevitably lead to loss of interest in participation in the EU research programmes, respectively in the upcoming Horizon 2020. This could at the end result in a negative ratio of national contribution and the EU financial contribution, which should definitely be avoided.

\section{Limitations and further research directions}

The biggest problem in making this paper was data availability, i.e. the inability to download data from CORDIS database in a user friendly format, suitable for further analysis. Additional 
problem was the lack of uniform data for university participants, since this data is stored in CORDIS database under various names. Improving the CORDIS database features could enhance future research of Framework programmes. Interesting research direction was given by Nokkala et al. (Nokkala et al., 2005) - it was tried to find correlation between positions in various university ranking lists and participation in FP6. This could be an interesting research direction for the future, especially for the analysis of CEE countries, rarely included in similar analysis.

\section{References}

1. Barber, M., Krueger, A., Krueger, T., Roediger-Schulga, T. (2006), "The network of European Union-funded collaborative research and development projects", Physical Review E, Vol. 73, pp. 036132

2. Vizek Vidović, V., Bjeliš, A. (2006), "Entrepreneurialism at the University of Zagreb or Managing the Sustainability for Change", Higher Education in Europe, Vol. 31, No. 2, pp. 157-193.

3. Breschi, S., Cusmano, L. (2004), "Unveiling the texture of a European Research Area: Emergence of oligarchic networks under EU Framework Programmes", International Journal of Technology Management, Vol. 27, No. 8, pp. 747-772.

4. Ernst, K., Irwin, R., Galsworthy, M., McKee, M., Charlesworth, K., Wismar, M. (2010), "Difficulties of tracing health research funded by the European Union", Journal of Health Services Research \& Policy, Vol. 15, No. 3, pp.133-136.

5. EC (2013), "Sixth FP7 Monitoring Report. Monitoring report 2013", available at http://ec.europa.eu/research/evaluations/pdf/archive/fp7_monitoring reports/6th_fp7 monitoring_report.pdf (12 August 2013)

6. "Funding schemes", available at http://cordis.europa.eu/fp7/what_en.html\#funding (30 June 2013)

7. Geuna, A. (1998), "Determinants of university participation in EU-funded R \& D cooperative projects," Research Policy, Vol. 26, No.6, pp. 677-687.

8. Gusmão, R. (2001), "Research networks as a means of European integration", Technology in Society, Vol. 23, No.3., pp. 383-393.

9. Jóźwiak, J. (2002), "Perspectives from East and Central Europe", Higher Education Policy, Vol. 15, No. 3, pp. 263-276.

10. Luukkonen, T. (2000), "Additionality of EU Framework Programmes", Research Policy, Vol. 29, No. 6, pp. 711-724.

11. Mataković, H. (2011), "Analiza participacije institucija iz Republike Hrvatske u Sedmom okvirnom programu, in Barilović, Z. (Ed.), Zbornik radova sa znanstveno-stručnog skupa s međunarodnim sudjelovanjem "Projekti i projektni menadžment", Visoka škola za poslovanje i upravljanje s pravom javnosti „Baltazar Adam Krčelić“, Zaprešić, pp. 565-575.

12. "Memorandum of Understanding on the Association of Republic of Croatia to the FP7", available at http://projects.unizg.hr/_download/repository/FP7_Memorandum_13.6.2007.ENG.pdf (20 July 2013)

13. MZOŠ (2008), "Akcijski plan za podizanje apsorpcijskog kapaciteta Republike Hrvatske za Sedmi okvirni program za istraživanje i tehnološki razvoj 2009. - 2010. (Action plan to raise the absorption capacity of the Croatia in the Seventh Framework Programme for Research and Technological Development 2009 - 2010t)", available at http://projects.unizg.hr/_download/repository/Akcijski_plan_potpisan.pdf (28 June 2013)

14. MZOŠ (2013), "Akciiski plan podizanja apsorpcijskog kapaciteta Republike Hrvatske za sudjelovanje u Okvirnim programima za istraživanje Europske unije 2013. - 2015. (Action plan to raise the absorption capacity of Croatia for participation in the Framework Programmes of the European Union for Research 2013 - 2015)", available at http://public.mzos.hr/fgs.axd? id=19518 (21 July 2013)

15. Ortega, J. L., Aguillo, I. F. (2010), "Describing national science and technology systems through a multivariate approach: country participation in the 6th Framework Programmes", Scientometrics, Vol. 84, No.2, pp. 321-330. 
16. Rauch, M., Sommer-Ulrich, J. (2012), "Participation of the Central and Eastern European EU Member States in the 7th Framework Programme: Analysis, Evaluation, Recommendations", Fraunhofer MOEZ.

17. "Pravilnik o uvjetima za izbor $\cup$ znanstvena zvanja (Regulation on the requirements for academic advancement)", Official gazette, 26/2013

18. "Research themes", available at http://cordis.europa.eu/fp7/what_en.html\#themes (27 June 2013)

19. Rivera León, L., Reid, A. (2010), "Participation of South-East European countries in the competitive funding programmes for research in the European Commission", Report to UNESCO-BRESCE, Brussels, Technopolis Group.

20. Rodríguez, H., Fisher, E., Schuurbiers, D. (2013), "Integrating science and society in European Framework Programmes: Trends in project-level solicitations", Research Policy, Vol. 42, No. 5, pp. 1126-1137.

21. Roediger-Schluga, T., Barber, M. J. (2008), "R\&D collaboration networks in the European Framework Programmes: data processing, network construction and selected results", International Journal of Foresight and Innovation Policy, Vol. 4, No. 3/4, pp. 321-347.

22. Smith, D. (2013), "EU projekti na Institutu Ruđer Bošković (EU projects at Ruđer Bošković Institute)", available at http://transmedri.uniri.hr/files/DavidSmithRijeka.pdf (28 June 2013)

23. Švarc, J., Lažnjak, J., Perković, J. (2013), "Integration of the Western Balkan Countries and Turkey in the Framework Programmes: Some Empirical Evidence", Journal of European Integration, Vol. 35, No. 1, pp. 53-72.

24. "Teaching staff at institutions of higher education 2012/2013 academic year", available at http://www.dzs.hr/Hrv Eng/publication/2013/08-01-01 01 2013.htm (25 June 2013)

25. Vence, X., Guntin, X., Rodil, O. (2000), "Determinants of the Uneven Regional Participation of Firms in European Technology Programmes. The 'Low R\&D Trap'", European Planning Studies, Vol. 8, No. 1, pp. 29-42.

\section{About the authors}

Hrvoje Mataković, PhD, is a head of Research Office at Centre for Research, Development and Technology Transfer, University of Zagreb. Prior his engagement at University of Zagreb he was working as executive director of Transparency International Croatia. Since 2003 he is involved in preparation and implementation of various international projects. He was also lecturer at numerous workshops in Croatia and wider region on preparation of EU funded projects. Areas of his expertise include: anti-corruption policy; research policy; higher education policy and Europeanization of public policies. Author can be contacted at hrvoje.matakovic@unizg.hr

Iva Radočaj Novak, Msc, holds a Master of Science degree in Mathematics. From March 2012 she was employed as external expert at the Centre for Research, Development and Technology Transfer at the University of Zagreb, working on „University of Zagreb Research Capacities" project. Currently she is employed as technology analyst at the Technology Transfer Office at the University of Zagreb, working on „Building innovation support through efficient cooperation network" project. Her primary research interests lie in scientometrics. Author can be contacted at iva.radocaj.novak@unizg.hr 